\title{
HUBUNGAN KECERDASAN EMOSIONAL, KEDISIPLINAN BELAJAR DAN MOTIVASI BELAJAR DENGAN HASIL BELAJAR PESERTA DIDIK KELAS XI IPA SMA DI KECAMATAN TERNATE TENGAH
}

\author{
Herawati HM, Sudding ${ }^{1}$, Muhammad Syahrir ${ }^{2}$ \\ ${ }^{1,2}$ Dosen Program Pascasarjana Universitas Negeri Makassar \\ Email: herawati.hm93@gmail.com
}

Penelitian ini merupakan penelitian ex-post facto yang bertujuan untuk mengungkapkan seberapa besar hubungan kecerdasan emoisonal, kedisiplinan belajar dan motivasi belajar dengan hasil belajar peserta didik kelas XI IPA SMA di Kecamatan Ternate Tengah tahun pelajaran 2017/2018. Total populasi penelitian sebanyak 322 peserta didik dengan ukuran sampel sebanyak 181 peserta didik. Teknik penentuan sampel dilakukan dengan menggunakan disproportionate stratified cluster random sampling. Pengambilan data penelitian menggunakan instrumen berupa angket dan tes. Data penelitian dianalisis menggunakan Software SPSS. Hasil penelitian menunjukkan bahwa (1) sebagian besar peserta didik kelas XI IPA SMA di Kecamatan Ternate Tengah memiliki kecerdasan emosional dan kedisiplinan belajar pada kategori sangat tinggi, motivasi belajar berada pada kategori tinggi dan sangat tinggi, sedangkan hasil belajar berada pada kategori sangat rendah, (2) kecerdasan emosional, kedisiplinan belajar, dan motivasi belajar masing-masing memiliki hubungan positif dengan hasil belajar peserta didik, (3) terdapat hubungan postif antara kecerdasan emosional dan kedisiplinan belajar dengan hasil belajar peserta didik, kecerdasan emosional dan motivasi belajar dengan hasil belajar peserta didik, serta kedisiplinan belajar dan motivasi belajar dengan hasil belajar peserta didik, dan (4) terdapat hubungan linear antara kecerdasan emosional, kedisiplinan belajar dan motivasi belajar secara bersama-sama dengan hasil belajar peserta didik.

Kata Kunci: kecerdasan emosional, kedisiplinan belajar, motivasi belajar, hasil belajar.

\begin{abstract}
The study is ex-post factor which aims at discovering the extent of correlation of emotional intelligence, learning discipline, and learning motivation on learning result of Grade XI IPA students at SMA (senior high school) in Ternate Tengah subsdistrict of academic year 2017/2018. The total population was 322 students with 181 samples. Samples were obtained by employing disproportionate stratified cluster random sampling. Data were obtained by employing instruments of questionnaire and test. Data were analyzed by using SPSS software. The result of the study reveal that (1) most of the students of grade XI IPA at SMA in Ternate Tengah subdistrict had emotional intelligence and learning discipline in very high category, learning motivation in high and very high category; whereas, the learning result is in very low category, (2) the emotional intelligence, learning discipline, and learning motivation each had positive correlation with students learning result, (3) there is positive correlation between emotional intelligence and learning discipline; emotional intelligence and learning motivation on learning result; and learning discipline and learning motivation on learning result, (4) there is linear correlation between emotional intelligence, learning discipline, and learning motivation collaboratively on syudents learning result.
\end{abstract}

Keywords: Emotional Intelligence, Learning Discipline, Learning Motivation, Learning Achievement. 


\section{PENDAHULUAN}

Mutu pendidikan yang baik adalah yang menunjukkan hasil belajar peserta didik yang tinggi. Namun hasil belajar peserta didik di Indonesia menjadi salah satu masalah yang sedang dihadapi saat ini dikarenakan tingkat pencapaian hasil belajar yang rendah. Salah satu indikator yang menunjukkan bahwa mutu pendidikan di Indonesia masih rendah adalah hasil penelitian internasional tentang hasil belajar peserta didik. Survei yang dilakukan oleh Programme for International Students Assessment (PISA) pada tahun 2015 menunjukkan bahwa kemampuan sains peserta didik di Indonesia berada pada peringkat 62 dari 72 negara peserta survei yang tergabung dalam Organisation for Economic Co-Operation Development (OECD) dengan skor rata-rata 386. Hasil belajar yang rendah dan hasil survei tersebut tidak terlepas dari berbagai faktor yang mempengaruhinya.

Banyak faktor yang mempengaruh hasil belajar antara lain faktor eksternal yang mencakup aspek lingkungan fisik seperti lingkungan sekolah, kondisi sarana dan prasarana belajar, materi pembelajaran dan proses pembelajaran, sedangkan faktor internal mencakup aspek fisik seperti panca indera serta aspek psikologis seperti bakat, minat, kedisiplinan, kecerdasan emosional dan motivasi peserta didik.

Faktor internal yang diduga kuat mempengaruhi hasil belajar kimia peserta didik adalah kecerdasan emosional. Kecerdasan emosional, kecerdasan sosial dan kecerdasan spiritual berdasarkan penelitian memiliki kontribusi $80 \%$ terhadap kesuksesan hidup seseorang, sedangkan kecerdasan intelektual (IQ) hanya memberi kontribusi 20\% (Goleman, 2009). Kecerdasan emosional merupakan kemampuan mengelola emosi saat berhubungan dengan orang lain dimana unsur terpenting dalam kecerdasan emosional adalah empati dan kontrol diri (Khodijah, 2014). Selain kecerdasan emosional, faktor lain yang mempengaruhi hasil belajar adalah motivasi. Sardiman (2012) menyatakan bahwa: "Motivasi berasal dari kata 'Motif' yang diartikan sebagai daya upaya yang mendorong seseorang untuk melakukan sesuatu". Sependapat dengan Sardiman, Uno (2008) menyatakan bahwa "motivasi berasal dari kata motif yang dapat diartikan sebagai tenaga penggerak yang mempengaruhi kesiapan untuk memulai melakukan rangkaian kegiatan dalam suatu perilaku". Setiap aktivitas yang dilakukan seseorang selalu didorong adanya kekuatan dari dalam diri orang tersebut. Kekuatan yang mendorong orang untuk melakukan perbuatan inilah yang disebut motif.

Kecerdasan emosional memiliki hubungan yang erat dengan motivasi. Orang yang memiliki kecerdasan emosional akan dapat memotivasi dirinya. Dalam hal ini berarti memiliki ketekunan untuk menahan diri terhadap kepuasan dan mengendalikan dorongan hati, serta mempunyai perasaan motivasi yang positif yaitu antuasisme, gairah, optimis dan keyakinan diri. Hal ini diperkuat oleh hasil penelitian yang dilakukan oleh Ilyas (2013) menunjukkan bahwa kecerdasan emosional dan motivasi belajar memiliki hubungan positif yang signifikan dengan hasil belajar peserta didik. Selain itu penelitian yang dilakukan oleh Nasution $d k k$, (2014) menunjukkan terdapat hubungan positif yang signifikan dengan interpretasi cukup antara kecerdasan emosional (EQ) dan motivasi belajar dengan hasil belajar kimia peserta didik.

Selain kecerdasan emosional dan motivasi, faktor internal lain yang mempengaruhi hasil belajar adalah kedisiplinan belajar. Kedisiplinan belajar adalah kesadaran diri yang muncul dari dalam diri peserta didik untuk mengikuti dan menaati peraturan-peraturan, nilai-nilai dan hukum yang berlaku di lingkungan belajar (Tu'u, 2004). Melalui kedisiplinan belajar seorang peserta didik dapat melaksanakan aktivitas kesehariannya 
mulai dari bangun pagi sampai tidur kembali pada malam hari. Peserta didik yang memiliki disiplin belajar yang baik akan memiliki ketaatan terhadap aturan baik peraturan sekolah, jam belajar dan penggunaan waktu luang.

Hal ini diperkuat oleh hasil penelitian yang dilakukan oleh Figrawati (2015) yang mengatakan bahwa kecerdasan emosional dan kedisiplinan belajar memiliki hubungan positif yang signifikan dengan hasil belajar peserta didik kelas XI IPA. Penelitian yang dilakukan oleh Ilyas (2013) menunjukkan bahwa kecerdasan emosional dan motivasi belajar memiliki

\section{METODE PENELITIAN}

Jenis penelitian ini adalah penelitian "ex-post facto" karena faktor yang dikumpulkan sudah ada sebelumnya pada diri responden atau gejala muncul tanpa adanya perlakuan, dan bersifat "korelasional" karena diselidiki hubungan antar variabel. Penelitian ini akan menerangkan hubungan antara kecerdasan emosional dan motivasi belajar dengan hasil belajar peserta didik.

Populasi dalam penelitian ini yaitu seluruh peserta didik kelas XI IPA SMA di Kecamatan Ternate Tengah Kota Ternate tahun ajaran 2017/2018 yang terdiri dari 2 SMA Negeri yaitu SMA Negeri 1 Kota Ternate dan SMA Negeri 10 Kota Ternate, serta 2 SMA Swasta yaitu SMA Swasta Islam Kota Ternate dan SMA Swasta Katolik Bintang Laut Kota Ternate. Daftar sekolah di Kecamatan Ternate Tengah. Pengambilan sampel dalam penelitian ini akan menggunakan teknik disproportionate stratified cluster random sampling. Jadi dari populasi sebanyak 340 peserta didik, banyaknya sampel yang digunakan dalam penelitian ini adalah 181 peserta didik.

Untuk memperoleh skor variabel penelitian, akan digunakan 5 instrumen yang terdiri atas dua bentuk, yaitu angket dan tes. Angket dalam penelitian ini berupa angket kecerdasan emosional, kedisplinan hubungan positif yang signifikan dengan hasil belajar peserta didik.

Dengan demikian jika kecerdasan emosional peserta didik baik, maka peserta didik akan memiliki kedisiplinan belajar yang baik sehingga motivasi belajarnya akan tinggi yang akan mempengaruhi hasil belajar peserta didik. Oleh sebab itu, peneliti tertarik untuk mengetahui hubungan-hubungan tersebut melalui prosedural ilmiah dengan mengangkat judul "Hubungan Kecerdasaan Emosional, Kedisiplinan Belajar dan Motivasi Belajar dengan Hasil Belajar Peserta Didik Kelas XI IPA SMA Di Kecamatan Ternate Tengah".

belajar dan motivasi belajar peserta didik. Adapun instrumen dalam bentuk tes yang akan digunakan yaitu tes hasil belajar peserta didik pada mata pelajaran kimia.

Validitas yang digunakan peneliti dalam penlitian ini yaitu validitas isi dan validitas konstruk. Validitas sering digunakan dalam penelitian hasil belajar. Tujuannya untuk mengetahui sejauh mana peserta didik menguasai materi pelajaran yang telah disampaikan dan perubahanperubahan psikologis apa yang timbul pada diri peserta didik tersebut setelah proses pembelajaran.

Pegumpulan data akan dilakukan secara langsung artinya data diperoleh dengan meminta responden untuk mengisi angket tanpa perantara orang lain. Data kecerdasan emosional, kedisiplinan belajar dan motivasi belajar peserta didik akan diperoleh melalui pemberian angket kepada setiap responden (peserta didik) yang terpilih sebagai sampel. Angket tersebut selanjutnya diisi oleh responden, kemudian diperiksa dan diberi skor berdasarkan alternatif pilihan yang dipilih oleh responden. Data hasil belajar kimia peserta didik akan diperoleh melalui pemberian tes hasil belajar kepada peserta didik yang terpilih sebagai sampel penelitian. Tes tersebut berbentuk pilihan ganda yang dibuat berdasarkan indikator-indikator 
mata pelajaran kimia yang telah dipelajari peserta didik dalam proses belajar mengajar khususnya pada materi asam basa, titrasi asam basa dan hidrolisis garam.

Data yang telah dikumpulkan selanjutnya akan dianalisis menggunakan statistika deskiptrif dan statistika inferensial. Statistik deskriptif adalah statistik yang digunakan untuk menganalisis data dengan cara mendeskripsikan atau menggambarkan data yang telah diperoleh sebagaimana adanya, tanpa bermaksud membuat kesimpulan yang berlaku umum (Sugiyono, 2008). Analisis deskriptif digunakan untuk mendeskripsikan karakteristik hasil belajar peserta didik. Untuk pengkategorian skor hasil belajar digunakan kriteria berdasarkan pengkategorian skala lima dengan interval yang tertera pada Tabel 1 (Sappaile, 2013).

Tabel 1 Pengkategorian Skor Hasil

\begin{tabular}{cc}
\multicolumn{2}{c}{ Belajar } \\
\hline Nilai Hasil Belajar & Kategori \\
\hline $90-100$ & Sangat Tinggi \\
$80-89$ & Tinggi \\
$65-79$ & Cukup \\
$55-64$ & Rendah \\
$0-54$ & Sangat Rendah \\
\hline
\end{tabular}

Sumber: Baso Intang Sappaile (2013)

Analisis deskriptif yang akan dilakukan terhadap data kecerdasarn emosional, kedisiplinan belajar dan motivasi belajar perserta didik dikategorikan secara kualitatif. Statistik inferensial dipakai untuk keperluan pengujian hipotesis, yakni digunakan analisis korelasi pearson dan analisis regresi ganda.

\section{HASIL DAN PEMBAHASAN}

1. Gambaran Kecerdasan Emosional, Kedisiplinan Belajar, Motivasi Belajar dan Hasil Belajar Peserta Didik

Berikut ini gambaran kecerdasan emosional, kedisiplinan belajar, motivasi belajar dan hasil belajar peserta didik yang diperoleh berdasarkan skor masing-masing variabel.

\section{a. Kecerdasan Emosional}

Gambaran skor variabel kecerdasan emosional pada peserta didik kelas XI IPA SMA di Kecamatan Ternate Tengah disajikan dalam Tabel 2 dan kategori skor kecerdasan emosional peserta didik disajikan dalam Tabel 3.

Tabel 2 Statistik Skor Kecerdasan Emosional Peserta Didik

\begin{tabular}{cc}
\hline Satistik & Nilai Statistik \\
\hline Ukuran Sampel & 181,00 \\
Nilai Total & 23328,00 \\
Skor Tertinggi & 165,00 \\
Skor Terendah & 96,00 \\
Skor Rata-rata & 128,88 \\
Standar Deviasi & 14,68 \\
\hline
\end{tabular}

Tabel 3 Distribusi Presentase Skor Kecerdasan Emosional

\begin{tabular}{ccc}
\hline $\begin{array}{c}\text { Kategori } \\
\text { Skor }\end{array}$ & $\begin{array}{c}\text { Frekuen } \\
\text { si }\end{array}$ & $\begin{array}{c}\text { Presentase } \\
(\mathbf{\%})\end{array}$ \\
\hline Sangat & 0 & 0 \\
Rendah & 0 & 0 \\
Rendah & 4 & 2 \\
Sedang & 62 & 34 \\
Tinggi & 115 & 64 \\
Sangat Tinggi & & \\
\hline Jumlah & $\mathbf{1 8 1}$ & $\mathbf{1 0 0}$ \\
\hline
\end{tabular}

\section{b. Kedisiplinan Belajar}

Gambaran skor variabel kedisiplinan belajar pada peserta didik kelas XI IPA SMA di Kecamatan Ternate Tengah disajikan dalam Tabel 4 dan kategori skor kedisiplinan belajar peserta didik disajikan dalam Tabel 5.

Tabel 4 Statistik Skor Kedisiplinan Belajar Peserta Didik

\begin{tabular}{cc}
\hline Satistik & Nilai Statistik \\
\hline Ukuran Sampel & 181,00 \\
Skor Total & 6871,90 \\
Skor Tertinggi & 52,50 \\
Skor Terendah & 20,00 \\
Skor Rata-rata & 37,97 \\
\hline
\end{tabular}


Standar Deviasi

7,29

Tabel 5 Distribusi Presentase Skor

Kedisiplinan Belajar

\begin{tabular}{ccc}
\hline $\begin{array}{c}\text { Kategori } \\
\text { Skor }\end{array}$ & Frekuensi & $\begin{array}{c}\text { Presentase } \\
(\mathbf{\%})\end{array}$ \\
\hline Sangat & 0 & 0 \\
Rendah & 9 & 5 \\
Rendah & 30 & 17 \\
Sedang & 66 & 26 \\
Tinggi & 76 & 42 \\
Sangat Tinggi & & \\
\hline Jumlah & $\mathbf{1 8 1}$ & $\mathbf{1 0 0}$ \\
\hline
\end{tabular}

\section{c. Motivasi Belajar}

Gambaran skor variabel motivasi

belajar pada peserta didik kelas XI IPA SMA di Kecamatan Ternate Tangah disajikan dalam Tabel 6 dan kategori skor motivasi belajar peserta didik disajikan dalam Tabel 7.

Tabel 6 Statistik Skor Motivasi Belajar Peserta Didik

\begin{tabular}{cc}
\hline Satistik & Nilai Statistik \\
\hline Ukuran Sampel & 181,00 \\
Skor Total & 8676,00 \\
Skor Tertinggi & 65,00 \\
Skor Terendah & 30,00 \\
Skor Rata-rata & 47,94 \\
Standar Deviasi & 7,57 \\
\hline
\end{tabular}

Tabel 7 Distribusi Presentase Skor Motivasi Belajar

\begin{tabular}{ccc}
\hline $\begin{array}{c}\text { Kategori } \\
\text { Skor }\end{array}$ & $\begin{array}{c}\text { Frekuen } \\
\text { si }\end{array}$ & $\begin{array}{c}\text { Presentase } \\
(\boldsymbol{\%})\end{array}$ \\
\hline Sangat & 0 & 0 \\
Rendah & 0 & 0 \\
Rendah & 18 & 10 \\
Sedang & 78 & 43 \\
Tinggi & 85 & 47 \\
Sangat Tinggi & & \\
\hline Jumlah & $\mathbf{1 8 1}$ & $\mathbf{1 0 0}$ \\
\hline
\end{tabular}

\section{d. Hasil Belajar}

Gambaran skor variabel hasil belajar pada peserta didik kelas XI IPA SMA di Kecamatan Ternate Tangah disajikan dalam
Tabel 8 dan kategori skor hasil belajar peserta didik disajikan dalam Tabel 9.

Tabel 8 Statistik Skor Hasil Belajar Peserta Didik

\begin{tabular}{cc}
\hline Satistik & Nilai Statistik \\
\hline Ukuran Sampel & 181,00 \\
Skor Total & 10654,35 \\
Skor Tertinggi & 84,78 \\
Skor Terendah & 32,61 \\
Skor Rata-rata & 58,86 \\
Standar Deviasi & 13,90 \\
\hline
\end{tabular}

Tabel 9 Distribusi Presentase Skor Hasil Belajar

\begin{tabular}{ccc}
\hline $\begin{array}{c}\text { Kategori } \\
\text { Skor }\end{array}$ & Frekuensi & $\begin{array}{c}\text { Presentase } \\
(\boldsymbol{\%})\end{array}$ \\
\hline Sangat & 67 & 37 \\
Rendah & 45 & 25 \\
Rendah & 50 & 28 \\
Cukup & 19 & 10 \\
Tinggi & 0 & 0 \\
Sangat Tinggi & & \\
\hline Jumlah & $\mathbf{1 8 1}$ & $\mathbf{1 0 0}$ \\
\hline
\end{tabular}

\section{Hasil Analisis Statistika Inferensial}

Berikut ini disajikan hasil analisis statistika inferensial yang terdiri atas uji asumsi dan uji hipotesis.

a. Uji Asumsi

1) Uji Multikolinearitas

Hasil output dari uji multikolinearitas menggunakan program SPSS disajikan dalam Tabel 10.

Tabel 10 Hasil Uji Multikolinearitas

\begin{tabular}{lc}
\hline \multicolumn{1}{c}{ Model } & $\begin{array}{c}\text { Collinearity } \\
\text { Statistics }\end{array}$ \\
\cline { 2 - 2 } & VIF \\
\hline Kecerdasan & 2,583 \\
Emosional & \\
Kedisiplinan Belajar & 1,570 \\
Motivasi Belajar & 2,251 \\
\hline \multicolumn{2}{c}{ Berdasarkan hasil pengujian dengan } \\
SPSS diperoleh nilai Variance Inflation \\
Factor (VIF) ketiga variabel (kecerdasan \\
emosional, kedisiplinan belajar dan \\
motivasi belajar) lebih kecil dari 5 (VIF < \\
5), sehingga dapat dikatakan bahwa antar
\end{tabular}


variabel bebas tidak terjadi persoalan multikolinearitas.

2) Uji Linearitas

Uji linearitas bertujuan untuk mengetahui apakah dua variabel mempunyai hubungan yang linear atau tidak seacara signifikan. Pada taraf signifikan 0,05 , dua variabel dikatakan mempunyai hubungan linear nilai signifikansi lebih besar dari 0,05. Tabel 11 disajikan hasil output dari uji linearitas antara variabel bebas dengan variabel terikat menggunakan SPSS.

Tabel 11 Hasil Uji Linearitas Antara Variabel Kecerdasan Emosional dengan Hasil Belajar

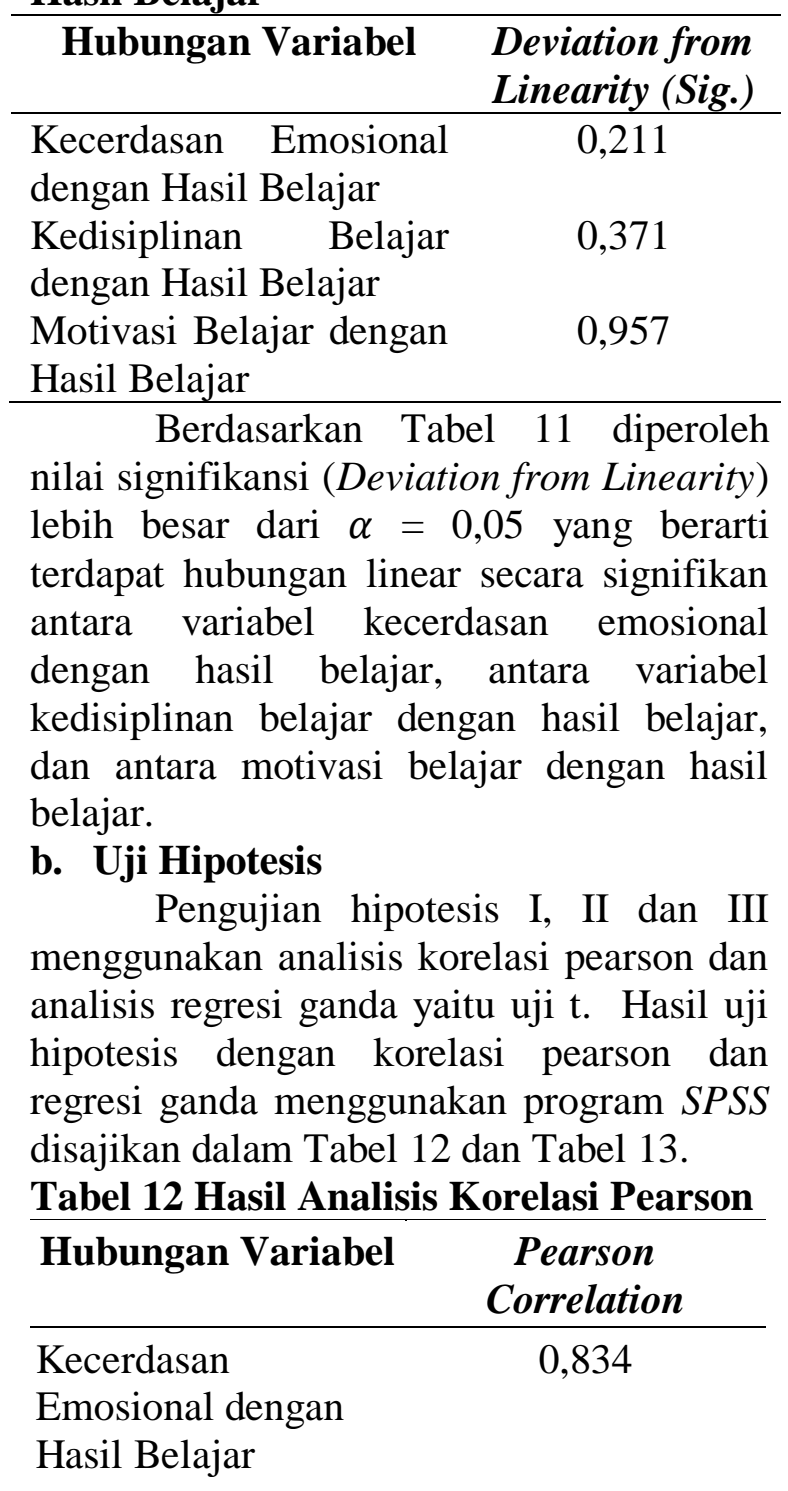

Kedisiplinan Belajar

0,618 dengan Hasil Belajar

Motivasi Belajar 0,720

dengan Hasil Belajar

Tabel 13 Hasil Analisis Regresi Ganda (Uji t)

\begin{tabular}{lc}
\hline \multicolumn{1}{c}{ Hubungan Variabel } & Uji t \\
\hline $\begin{array}{l}\text { Kecerdasan Emosional } \\
\text { dengan Hasil Belajar }\end{array}$ & 9,462 \\
$\begin{array}{l}\text { Kedisiplinan Belajar } \\
\text { dengan Hasil Belajar }\end{array}$ & 3,502 \\
$\begin{array}{l}\text { Motivasi Belajar dengan } \\
\text { Hasil Belajar }\end{array}$ & 3,457 \\
\hline
\end{tabular}

Tabel 14 Hubungan Indikator Kecerdasan Emosional dengan Hasil Belajar

\begin{tabular}{lcc}
\hline \multicolumn{1}{c}{ Indikator } & Beta & Sig. \\
\hline Kecerdasan Emosi Diri & 0,117 & 0,019 \\
Penilaian Diri & 0,076 & 0,123 \\
Percaya Diri & 0,060 & 0,270 \\
Pengendalian Diri & 0,059 & 0,277 \\
Dapat Dipercaya & 0,196 & 0,001 \\
Inovatif & 0,061 & 0,274 \\
Dorongan Berprestasi & 0,050 & 0,339 \\
Komitmen & 0,038 & 0,450 \\
Insiatif & 0,137 & 0,018 \\
Optimis & 0,072 & 0,204 \\
Memaham Orang Lain & 0,108 & 0,062 \\
Orientasi Pelayanan & 0,116 & 0,013 \\
Mengembangkan Orang & 0,063 & 0,234 \\
Lain & & \\
Mendayagunakan & 0,119 & 0,020 \\
Keragaman & 0,055 & 0,319 \\
Pengaruh & 0,078 & 0,198 \\
Komunikasi & 0,023 & 0,669 \\
Manajemen Konflik & 0,146 & 0,008 \\
Kepemimpinan & 0,063 & 0,246 \\
Katalisator Perubahan & Sebelum dilanjutkan pada uji \\
\hline \multicolumn{1}{c}{ pora }
\end{tabular}
hipotesis IV, V dan VI maka dilakukan analisis jalur untuk melihat pengaruh satu 
variabel bebas terhadap variabel terikat berdasarkan indikator. Hasil analisis jalur ditunjukkan pada Tabel 14, Tabel 15 dan Tabel 16.

Tabel 15 Hubungan Indikator Kedisiplinan Belajar dengan Hasil Belajar

\begin{tabular}{lcc}
\hline \multicolumn{1}{c}{ Indikator } & Beta & Sig. \\
\hline Waktu Belajar di Rumah & 0,090 & 0,274 \\
Rajin dan Teratur Belajar & 0,129 & 0,086 \\
Perhatian Belajar di Kelas & 0,219 & 0,023 \\
Ketertiban di kelas & 0,165 & 0,053 \\
Pemahaman aturan & 0,033 & 0,695 \\
perilaku & 0,167 & 0,026 \\
Sikap Kelakuan &
\end{tabular}

Tabel 16 Hubungan Indikator Motivasi Belajar dengan Hasil Belajar

\begin{tabular}{lcc}
\hline \multicolumn{1}{c}{ Indikator } & Beta & Sig. \\
\hline Minat & 0,146 & 0,032 \\
Tekun/Kegigihan & 0,177 & 0,006 \\
Usaha & 0,110 & 0,117 \\
Ulet & 0,162 & 0,016 \\
Mandiri & 0,092 & 0,176 \\
Cepat Bosan & 0,241 & 0,000 \\
Prestasi & 0,112 & 0,079 \\
\hline
\end{tabular}

Tabel 17 Hasil Analisis Regresi Ganda Antara Variabel Bebas dengan Variabel Terikat

\begin{tabular}{|c|c|c|}
\hline Hubungan Variabel & $F$ & $\begin{array}{c}R \\
\text { Square }\end{array}$ \\
\hline 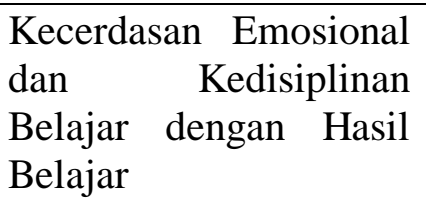 & 228,242 & 0,707 \\
\hline $\begin{array}{l}\text { Kecerdasan Emosional } \\
\text { dan Motivasi Belajar }\end{array}$ & 227,714 & 0,719 \\
\hline
\end{tabular}

dengan Hasil Belajar

$135,907 \quad 0,604$

Kedisiplinan Belajar dan Motivasi Belajar dengan Hasil Belajar

$$
165,504 \quad 0,737
$$

Kecerdasan Emosional,

Kedisiplinan Belajar, dan Motivasi Belajar dengan Hasil Belajar

Untuk menguji hipotesis IV, V, dan VI yaitu adanya pengaruh secara simultan antara kecerdasan emosional, kedisiplinan belajar dan motivasi belajar dengan hasil belajar peserta didik maka dapat dilihat dari hasil analisis pada Tabel 17.

\section{Pembahasan Hasil Penelitian}

\section{Hubungan Kecerdasan Emosional dengan Hasil Belajar Peserta Didik}

Berdasarkan hasil analisis data maka diperoleh fakta bahwa secara umum kecerdasan emosional peserta didik kelas XI IPA SMA di Kecamatan Ternate Tengah berada pada kategori skor kecerdasan emosional sangat tinggi. Hal ini mengindikasi bahwa peserta didik kelas XI IPA SMA di Kecamatan Ternate tengah rata-rata mampu mengatur kehidupan emosinya dengan intelegensi, menjaga keselarasan emosi dengan pengungkapannya melalui keterampilan kesadaran diri, pengendalian diri, motivasi diri, empati dan keterampilan sosial (Goleman, 2004).

Berdasarkan hasil uji hipotesis pada Tabel 12 dapat dikatakan bahwa terdapat korelasi atau hubungan antara kecerdasan emosional dengan hasil belajar peserta didik dimana korelasi berada pada tingkat korelasi sempurna. Pada Tabel 13 hasil analisis regresi ganda dapat disimpulkan bahwa $\mathrm{H}_{0}$ ditolak dan $\mathrm{H}_{1}$ diterima artinya terdapat hubungan antara kecerdasan emosional dengan hasil belajar peserta didik pada tingkat korelasi sempurna. Hal ini konsinten pada penelitian sebelumnya yang dilakukan oleh Syarif \& Munandar (2017) yang menunjukkan bahwa terdapat 
hubungan positif antara kecerdasan emosional dengan hasil belajar, dimana hubungan ini mengandung arti semakin tinggi kecerdasan emosional maka semakin tinggi hasil belajar peserta didik.

Berdasarkan analisis alur hubungan setiap indikator kecerdasan emosional dengan hasil belajar, diketahui bahwa indikator yang mempengaruhi hasil belajar peserta didik yaitu kecerdasan emosi diri, dapat dipercaya, inisiatif, orientasi pelayanan, mendayagunakan keragaman, dan kepemimpinan. Indikator yang memliki pengaruh paling besar adalah indikator dapat dipercaya dengan nilai koefisien Beta sebesar 0,196. Indikator dapat dipercaya artinya peserta didik tersebut memiliki tanggung jawab yang tinggi dalam mengeolah diri sendiri. Kemampuan mengelolah diri sendiri dapat menjadikan peserta didik menjadi orang yang bertanggung jawab terhadap tugas yang diberikan.

Aspek emosional dapat mempengaruhi perkembangan pribadi anak dalam mencapai kesehatan mental, kreativitas dan aktualisasi diri, sehingga akan berdampak pada sikapnya dalam belajar dan mempengaruhi hasil belajarnya (Hamzah \& Kuadrat, 2009). Orang yang mampu mengenali emosi dirinya menyadari kekuatan dan kelemahannya, dapat menempatkan diri untuk merenung dan belajar dari pengalamannya, bersedia menerima perspektif baru, dan mau terus belajar untuk mengembangkan diri sendiri (Yahaya et al, 2012). Individu dengan keterampilan emosional yang berkembang baik berarti kemungkinan besar ia akan berhasil dalam kehidupan dan memiliki motivasi untuk berprestasi. Sedangkan individu yang tidak dapat menahan kendali atas kehidupan emosionalnya akan mengalami pertarungan batin yang merusak kemampuannya untuk memusatkan perhatian pada tugas-tugasnya dan memiliki pikiran yang jernih. Individu dengan tingkat kecerdasan emosional yang tinggi akan memiliki kualitas hidup yang lebih baik (Gayathri \& Meenakshi, 2013).

\section{Hubungan Kedisiplinan Belajar dengan Hasil Belajar}

Berdasarkan hasil analisis data diperoleh skor kedisiplinan belajar peserta didik kelas XI IPA SMA di Kecamatan Ternate Tengah secara umum berada pada kategori skor sangat tinggi artinya peserta didik mempunyai kedisiplinan belajar yang tinggi dalam pelajaran kimia. Fakta ini sebaiknya dipertahankan bahkan ditingkatkan sebab kedisiplinan belajar peserta didik merupakan salah satu faktor internal yang cukup besar pengaruhnya dalam menunjang hasil belajar peserta didik.

Berdasarkan uji hipotesis pada Tabel 12, hasil analisis korelasi pearson diperoleh bahwa terdapat korelasi atau hubungan antara kedisiplinan belajar dengan hasil belajar peserta didik dimana korelasi berada pada tingkat korelasi kuat. Pada Tabel 13 hasil analisis regresi ganda Uji $\mathrm{t}$ diketahui bahwa $\mathrm{H}_{0}$ ditolak dan $\mathrm{H}_{1}$ diterima artinya terdapat hubungan antara kedisiplinan belajar dengan hasil belajar peserta didik. Adapun hubungan kedua variabel tersebut berupa positif dan signifikan. Dikatakan positif dan signifikan bahwa hubungan tersebut berjalan secara berbanding lurus, artinya apabila peserta didik memiliki sikap disiplin yang termasuk dalam kategori tinggi, maka akan memperoleh hasil belajar yang optimal. Sebaliknya, apabila sikap disiplin peserta didik termasuk dalam kategori rendah maka hasil belajar yang diperoleh rendah (Tu'u, 2004).

Hal ini sejalan dengan penelitian yang dilakukan Whisman \& Hammer, (2015) yang meneliti tentang hubungan kedisiplinan peserta didik dengan prestasi dan bakat peserta didik. Diperoleh hasil bahwa peserta didik yang memiliki kedisiplinan yang tinggi juga memiliki prestasi belajar yang tinggi serta bakat yang banyak, sedangkan peserta didik dengan 
kedisiplinan rendah memiliki prestasi belajar rendah dan bakat yang sedikit.

Berdasarkan analisis alur hubungan setiap indikator kedisiplinan belajar dengan hasil belajar, diketahui bahwa indikator yang mempengaruhi hasil belajar peserta didik yaitu indikator perhatian belajar di kelas dan sikap kelakuan, dengan nilai koefisien Beta masing-masing sebesar 0,219 dan 0,167. Perhatian belajar di kelas adalah perhatian yang baik saat belajar di kelas berupa sikap dan tingakan melihat serta mendengarkan dengan sungguhsungguh terhadap sesuatu yang sedang dihadapi. Semakin tinggi perhatian belajar yang diberikan peserta didik pada pelajaran yang sedang berlangsung maka hasil belajar yang diperoleh akan semakin tinggi. Indikator sikap kelakuan adalah sikap yang menunjukkan kesungguhan dan kepatuhan terhadap peraturan yang ada di lingkungan sekolah. Terbentuknya kedisiplinan belajar dalam hal sikap kelakuan peserta didik dapat melalui tauladan dari guru. Apabila disiplin guru dan peserta didik sudah mulai tertanam maka akan terjadi iklim belajar yang efektif dan kondusif. Sebaliknya apabila tindakan guru dan peserta didik yang tidak sesuai dengan tata tertib maka akan menimbulkan berbagai permasalahan yang akan menyebabkan proses belajar mengajar yang tidak kondusif (Mulyasa, 2009).

\section{Hubungan Motivasi Belajar Terhadap Hasil Belajar}

Skor motivasi belajar peserta didik kelas XI IPA SMA di Kecamatan Ternate Tengah cenderung berada pada kategori skor tinggi dan sangat tinggi. Fakta ini sebaiknya dipertahankan sebab motivasi belajar peserta didik merupakan salah satu faktor internal yang cukup besar pengaruhnya dalam menunjang hasil belajar peserta didik.

Beradasarkan uji hipotesisi pada Tabel 12, hasil analisis korelasi pearson diperoleh bahwa terdapat korelasi atau hubungan antara motivasi belajar dengan hasil belajar peserta didik dimana korelasi berada pada tingkat korelasi kuat. Pada Tabel 13 hasil analisis regresi ganda dapat disimpulkan bahwa $\mathrm{H}_{0}$ ditolak dan $\mathrm{H}_{1}$ diterima artinya terdapat hubungan antara motivasi belajar dengan hasil belajar peserta didik. Hasil ini sejalan dengan penelitian yang dilakukan Az-Zahro \& Khoirunnisa, (2017) yang menunjukkan bahwa terdapat hubungan yang signifikan pada kategori kuat antara motivasi belajar dengan prestasi belajar kimia.

Motivasi belajar peserta didik merupakan daya penggerak dalam diri peserta didik untuk dapat mencapai hasil belajar peserta didik yang optimal, sehingga tujuan yang dikehendaki subjek belajar itu dapat tercapai. Motivasi itu dapat berasal dari diri pribadi peserta didik itu sendiri (motivasi intrinsik) dan berasal dari luar diri pribadi peserta didik (ekstrinsik) (Syah, 2017). Peserta didik yang mempunyai motivasi tinggi akan melaksanakan kegiatan belajarnya dengan penuh keyakinan dan tanggung jawab bila dibandingkan dengan peserta didik yang memiliki motivasi belajar rendah, sehingga akan mencapai hasil belajar yang optimal.

Berdasarkan analisis alur hubungan setiap indikator motivasi belajar dengan hasil belajar, diketahui bahwa indikator yang mempengaruhi hasil belajar peserta didik yaitu indikator minat, tekun/kegigihan, ulet dan cepat bosan. Dimana indikator cepat bosan dan tekun/kegigihan adalah indikator yang paling berpengaruh dengan nilai koefisien Beta sebesar 0,241 dan 0,177. Indikator cepat bosan dimaksudkan bahwa peserta didik merasa cepat bosan dengan kegiatan belajar yang dilakukan berulang-ulang tanpa ada kreatifitas lain. Pemberian materi pelajaran dengan cara yang monoton dan tidak melibatkan peserta didik akan membuat peserta didik merasa cepat bosan sehingga motivasi untuk belajar kimia menurun yang berakibat pada rendahnya hasil belajar kimia peserta didik. 
Sikap tekun yang dimiliki peserta didik sangat mempengaruhi hasil belajar peserta didik karena dengan ketekunan yang dimiliki peserta didik akan memperoleh kesuksesan dalam segala hal. Motivasi belajar yang tinggi tercemin dari ketekunan yang tidak mudah patah untuk mencapai sukses meskipun dihadang oleh berbagai kesulitan. Motivasi yang tinggi dapat menggiatkan aktivitas belajar peserta didik. Peserta didik yang mempunyai motivasi tinggi akan melaksanakan kegiatan belajarnya dengan penuh keyakinan dan tanggung jawab bila dibandingkan dengan peserta didik yang memiliki motivasi belajar rendah. sehingga akan mencapai hasil belajar yang optimal. Dengan demikian dapat disimpulkan bahwa peserta didik yang memiliki motivasi belajar tinggi mempunyai peluang lebih besar untuk memperoleh prestasi belajar yang lebih baik dibandingkan peserta didik yang memiliki motivasi belajar rendah (Riswanto \& Aryani, 2017).

Peserta didik dengan motivasi belajar yang tinggi selalu mencapai keberhasilan yang besar dalam pembelajaran, sementara peserta didik yang kurang motivasi tidak melakukan upaya dalam proses pembelajaran dan sering gagal dalam ujian. Jika seorang peserta didik tidak memiliki motivasi, tidak mungkin mencapai kesuksesan sedangkan peserta didik yang bermotivasi tinggi dapat berhasil dalam kondisi apapun (Li \& Pan, 2009).

\section{Hubungan Kecerdasan Emosional dan Kedisiplinan Belajar dengan Hasil Belajar}

Berdasarkan data pada Tabel 17 diperoleh nilai $\mathrm{F}$ hitung $=220,242$ lebih besar dari $\mathrm{F}$ Tabel $=3,05$, maka dapat dinyatakan bahwa terdapat hubungan secara linear antara kecerdasan emosional dan kedisiplinan belajar dengan hasil belajar peserta didik kelas XI IPA SMA di Kecamatan Ternate Tengah. Nilai koefisien determinasi $\left(\mathrm{R}^{2}\right)$ sebesar 0,707. Artinya terdapat pengaruh secara bersama-sama antara kecerdasan emosional dan kedisiplinan belajar dengan hasil belajar peserta didik kelas XI IPA SMA di Kecamatan Ternate Tengah sebesar 70,7\%. Hasil ini sejalan dengan penelitian yang dilakukan Ernawati (2015: 20) yang menunjukkan bahwa terdapat hubungan positif antara kecerdasan emosional dan kedisiplinan belajar terhadap hasil belajar peserta didik. Peningkatan kecerdasan emosional akan meningkatkan kedisiplinan belajar yang mengakibatkan hasil belajar ikut meningkat (Ngila \& Makewa, 2017).

Kecerdasan emosional dan kedisiplinan belajar saling mempengaruhi, dan keduanya secara positif mempengaruhi hasil belajar peserta didik. Kedisiplin belajar ada hubungannya dengan kemampuan peserta didik untuk mengendalikan emosi, perasaan, dan keinginan sehingga mencapai tujuan yang telah ditentukan (Knapczyk, 2004). Agar seorang individu dapat mengendalikan emosi dan keinginannya, individu harus mampu mengenali perasaannya sendiri, yaitu, memiliki kesadaran diri yang tinggi, yang merupakan komponen penting kecerdasan emosional (Gootman, 2001). Setelah mengidentifikasi emosi, peserta didik juga harus dapat mengarahkan emosi ke hal yang dapat diterima yang tidak akan mempengaruhi orang lain secara negatif. Seorang peserta didik yang memahami emosi dan perasaan orang lain (memiliki tingkat kecerdasan emosional yang tinggi) memiliki hubungan yang sehat dengan gurunya dan sesama pelajar (Brackett \& Mayer, 2003), dan mampu memprioritaskan kegiatan yang diarahkan untuk mencapai tujuan pribadi. Peserta didik yang memiliki kedisiplinan belajar yang tinggi kemungkinan besar cerdas secara emosional dan memiliki hasil belajar yang tinggi.

\section{Hubungan Kecerdasan Emosional dan Motivasi Belajar dengan Hasil Belajar}

Berdasarkan pada Tabel 17 diperoleh nilai $\mathrm{F}$ hitung $=227,714$ lebih 
besar dari $\mathrm{F}$ Tabel $=3,05$, maka dapat dinyatakan bahwa terdapat hubungan secara linear antara kecerdasan emosional dan motivasi belajar dengan hasil belajar peserta didik kelas XI IPA SMA di Kecamatan Ternate Tengah. Nilai koefisien determinasi $\left(\mathrm{R}^{2}\right)$ sebesar 0,719. Artinya terdapat pengaruh secara bersama-sama antara kecerdasan emosional dan motivasi belajar dengan hasil belajar peserta didik kelas XI IPA SMA di Kecamatan Ternate Tengah sebesar 71,9\%. Hasil ini sejalan dengan penelitian yang dilakukan Asry et al, (2017) yang menujukkan bahwa tinggi rendahnya hasil belajar yang dicapai peserta didik dipengaruhi oleh kecerdasan emosional dan motivasi belajar peserta didik.

Kecerdasan emosional peserta didik dipengaruhi oleh motivasi belajar yang secara bersama-sama dapat mempengaruhi hasil belajar peserta didik (ArribasGalarraga et al, 2017). Kecerdasan emosional memiliki peran yang sangat tinggi dalam perilaku positif seseorang, sering kali peserta didik terganggu saat ujian dan belajar ketika ada masalah yang berhubungan dengan dirinya sehingga terbawa hingga ke kemampuan menerima pelajaran, namun dengan kecerdasan emosional yang tinggi peserta didik dapat mengelola emosi sehingga masalah yang sedang dihadapi tidak menggangu pelajaran (Adawiyah, 2013). Peserta didik yang memiliki kecerdasan emosional tinggi dapat memotivasi dirinya untuk belajar sehingga memeproleh hasil belajar yang tinggi, begitupun sebaliknya, peserta didik yang memiliki kecerdasan emosional rendah tidak dapat memotivasi dirinya dalam belajar sehingga hasil belajar yang diperoleh rendah.

\section{Hubungan Kedisiplinan Belajar dan Motivasi Belajar dengan Hasil Belajar}

Berdasarkan pada Tabel 17 diperoleh nilai $\mathrm{F}$ hitung $=135,907$ lebih besar dari $\mathrm{F}$ Tabel $=3,05$, maka dapat dinyatakan bahwa terdapat hubungan secara linear antara kedisiplinan belajar dan motivasi belajar dengan hasil belajar peserta didik kelas XI IPA SMA di Kecamatan Ternate Tengah. Nilai koefisien determinasi $\left(\mathrm{R}^{2}\right)$ sebesar 0,604. Artinya terdapat pengaruh secara bersama-sama antara kedisiplinan belajar dan motivasi belajar dengan hasil belajar peserta didik kelas XI IPA SMA di Kecamatan Ternate Tengah sebesar $60,4 \%$. Hasil ini sejalan dengan penelitian yang dilakukan Jeffrey \& Zein (2017) yang menunjukkan bahwa motivasi belajar dan disiplin belajar memiliki pengaruh signifikan positif terhadap hasil belajar peserta didik.

Hubungan antara motivasi belajar dengan disiplin belajar merupakan hubungan yang positif. Hubungan yang positif berarti jika motivasi belajar siswa naik maka disiplin siswa juga naik, begitu pula sebaliknya (Agustin et al,, 2017). Agar prestasi belajar dapat diperoleh secara maksimal diperlukan kedisiplinan dalam belajar serta adanya motivasi belajar (Rahayu, 2015). Kedisiplinan siswa dalam belajar akan melatih dirinya untuk bisa mengendalikan diri, menghargai dan mentaati segala peraturan tata tertib yang ada di sekolah. Kedisiplinan belajar yang tinggi dapat meningkatkan motivasi belajar. Motivasi merupakan kekuatan yang menjadi pendorong kegiatan individu untuk melakukan kegiatan mencapai sesuatu tujuan (Sukmadinata, 2005). Dengan adanya motivasi belajar yang tinggi dari peserta didik maka akan ada dorongan, kekuatan, keinginan untuk belajar sehingga akan berdampak pada peningkatan hasil belajar.

7. Hubungan Kecerdasan Emosional, Kedisiplinan Belajar, dan Motivasi Belajar dengan Hasil Belajar

Berdasarkan pada Tabel 17 diperoleh nilai $\mathrm{F}$ hitung $=165,504$ lebih besar dari $\mathrm{F}$ Tabel $=2,66$, maka dapat dinyatakan bahwa terdapat hubungan secara linear antara kecerdasan emosional, 
kedisiplinan belajar dan motivasi belajar secara bersama-sama dengan hasil belajar peserta didik kelas XI IPA SMA di Kecamatan Ternate Tengah. Nilai koefisien determinasi $\left(\mathrm{R}^{2}\right)$ sebesar 0,732. Artinya terdapat pengaruh secara bersama-sama antara kecerdasan emosional, kedisiplinan belajar dan motivasi belajar dengan hasil belajar peserta didik kelas XI IPA SMA di Kecamatan Ternate Tengah sebesar 73,2\%. Sementara faktor lain sebesar $26,8 \%$ yang mempengaruhi hasil belajar peserta didik tidak diteliti dalam penelitian ini. Kecedasan emosional, kedisiplinan belajar dan motivasi belajar merupakan faktor yang sangat berpengaruh terhadap hasil belajar peserta didik sekaligus sebagai suatu hal yang saling terkait dan tidak dapat dikesampingkan. Semakin tinggi tingkat kecerdasan emosional, kedisiplinan belajar dan motivasi belajar maka semakin baik pula hasil belajar yang akan diperoleh peserta didik. Sebaliknya jika kecerdasan emosional, kedisiplinan belajar dan motivasi belajar peserta didik rendah maka hasil belajar yang dipeoleh juga rendah. Oleh karena itu, kecerdasan emosional, kedisiplinan belajar dan motivasi belajar yang tinggi dari peserta didik akan mendorong terjadinya peningkatan hasil belajar.

\section{SIMPULAN DAN SARAN}

Berdasarkan hasil analisis data penelitian dan pembahasan hasil penelitian, maka kesimpulan dari hasil penelitian ini adalah terdapat hubungan linear antara kecerdasan emosional. kedisiplinan belajar dan motivasi belajar secara bersama-sama dengan hasil belajar peserta didik kelas XI IPA SMA di Kecamatan Ternate Tengah sebesar $73,7 \%$.

\section{DAFTAR RUJUKAN}

Adawiyah, R.A.R. 2013. Kecerdasan Emosional, Dukungan Sosial dan
Kecenderungan Burnout. Jurnal Psikologi Indonesia, 2(2): 99-107.

Agustin, Y.T., Gunanto, Y.E. \& Listiani, T. 2017. Hubungan Motivasi Belajar dan Disiplin Belajar Siswa Kelas IX Pada Pembelajaran Matematika di Suatu Sekolah Kristen [The Relationship Between Learning Motivation and Learning Discipline Of Grade 9 Mathematics Students at A Christian School]. JOHME: Journal of Holistic Mathematics Education, 1(1): 32.

Anon. PISA - PISA.

http://www.oecd.org/pisa/ 24

October 2017.

Arribas-Galarraga, S., Saies, E., Cecchini, J.A., Arruza, J.A. \& Luis-De-Cos, I. 2017. The Relationship Between Emotional Intelligence, Selfdetermined Motivation and Performance in Canoeists. Journal of Human Sport and Exercise, 12(3).

http://hdl.handle.net/10045/69555 28 May 2018.

Asry, W., Jaya, I. \& Lubis, L. 2017. The Influence of Emotional Intelligence and Achievement Motivation to Learning Achievement of Akidah Akhlak Subject at Madrasah Aliyah Negeri 1 Medan. Journal of Humanities And Social Science, 22(8): 62-69.

Az-Zahro, A.F. \& Khoirunnisa, R.N. 2017. Hubungan Antara Motivasi Belajar Dengan Prestasi Belajar Mata Pelajaran Kimia Siswa SMAN 1 Gedangan. Jurnal Psikologi Pendidikan, 4(3).

Brackett, M.A. \& Mayer, J.D. 2003. Convergent, Discriminant, and Incremental Validity of Competing Measures of Emotional Intelligence. Personality and Social Psychology Bulletin, 29(9): 1147-1158.

Ernawati. 2015. Hubungan Kecerdasan Emosional dan Kedisiplinan Belajar 
Terhadap Hasil Belajar Siswa SMA Negeri di Kota Makassar. Jurnal Bionature, , 16(1): 17-20.

Gayathri, N. \& Meenakshi, D.K. 2013. A Literature Review of Emotional Intelligence. International Journal of Humanities and Social Science Invention, 2(3): 42-51.

Goleman, D. 2009. Emotional Intelligence. Mengapa EI Lebih Penting Daripada IQ. Jakarta: Gramedia Pustaka Utama.

Goleman, D. 2004. Primal leadership: kepemimpinan berdasarkan kecerdasan emosi. Jakarta: Gramedia Pustaka Utama.

Gootman, M.E. 2001. The Caring Teacher's Guide to Discipline: Helping Young Students Learn SelfControl, Responsibility, and Respect. Corwin Press.

Hamzah, B. \& Kuadrat, M. 2009. Mengelola Kecerdasan dalam Pembelajaran. Jakarta: Bumi Aksara.

Ilyas. 2013. Hubungan Kecerdasan Emosional dan Motivasi Belajar Fisika dengan Hasil Belajar Fisika Peserta Didik Kelas X SMA Negeri 1 Tinggimoncong. Tesis. Makassar: Universitas Negeri Makassar.

Jeffrey, D.I. \& Zein, A. 2017. The Effect of Achievement Motivation, Learning Discipline and Learning Facilities on Student Learning Outcomes. West Virginia Department of Education Division of Teaching and Learning Office of Research, 07: 8.

Khodijah, N. 2014. Psikologi Pendidikan. Jakarta: Rajagrafindo Persada (Rajawali Pers).

Knapczyk, D. 2004. Teaching Self Discipline for Self-Reliance and Academic Success. Verona: IEP Resources.

Li, P. \& Pan, G. 2009. The Relationship between Motivation and Achievement-A Survey of the
Study Motivation of English Majors in Qingdao Agricultural University. English Language Teaching, 2(1). http://www.ccsenet.org/journal/inde x.php/elt/article/view/347 13 May 2018.

Mulyasa, E. 2009. Standar Kompetensi dan Sertifikasi Guru. Bandung: Rosdakarya.

Nasution, H.I., Dewi, R.S. \& Harahap, H.J.B. 2014. HUBUNGAN KECERDASAN EMOSIONAL (EQ) DAN MOTIVASI BELAJAR TERHADAP HASIL BELAJAR KIMIA SISWA SMA. Jurnal Pendidikan Kimia, 6(3): 9.

Ngila, W.M. \& Makewa, L.N. 2017. Student Emotional Intelligence and Self Discipline in Secondary Schools in Kenya. Journal of Research Innovation and Implications in Education, 1(3): 8295.

Rahayu, T. 2015. Hubungan Antara Kedisiplinan dan Motivasi Belajar Sosiologi Siswa SMA Negeri 1 Teras Boyolali. Jurnal Ilmiah Pend. Sos Ant, 6(2): 10.

Riswanto, A. \& Aryani, S. 2017. Learning motivation and student achievement: description analysis and relationships both. COUNSEDU: The International Journal of Counseling and Education, 2(1): 42.

Sappaile, B.I. 2013. Pengkategorian Responden Berdasarkan Skor Total.

Sardiman. 2012. Interaksi dan Motivasi Belajar Mengajar. Jakarta: Rajagrafindo Persada (Rajawali Pers).

Sugiyono. 2008. Metode penelitian pendidikan: (pendekatan kuantitatif, kualitatif dan $R$ \& $D$ ). Bandung: Alfabeta.

Sukmadinata, N.S. 2005. Landasan Psikologi Proses Pendidikan. Bandung: Remaja Rosdakarya. 
Syah, M. 2017. Psikologi Pendidikan dengan Pendekatan Baru. Bandung: Remaja Rosdakarya.

Syarif, S.H. \& Munandar, H. 2017. Hubungan Kecerdasan Emosional dengan Hasil Belajar Siswa Kelas XI IPA SMA Negeri di Kota Parepare pada Mata Pelajaran Kimia. Jurnal Chemica, 18(1): 3947.

Tu'u, T. 2004. Peran Disiplin Pada Perilaku dan Prestasi Siswa. Grasindo.

Uno, H.B. 2008. Teori Motivasi dan Pengukurannya. Jakarta: Bumi Aksara.

Whisman, A. \& Hammer, P.C. 2015. The Association Between School Discipline and Mathematics Performance. West Virginia Department of Education Divi Office of Research: 26.

Yahaya, A., Ee, N.S., Hashim, S. \& Lee, G.M. 2012. The Impact of Emotional Intelligence Element on Academic Achievement. Archives Des Sciences, 65(4): 16. 